\title{
Effect of foliar spraying with algae suspension on leaf and fruit quality parameters of apple varieties
}

\author{
Nagy, P. T. ${ }^{1}$, Ambrus, A. ${ }^{2}$, Nyéki, J. ${ }^{3}$, Soltész, M. ${ }^{4}$ \& Szabó, Z. ${ }^{3}$ \\ ${ }^{1}$ Institute of Environmental Sciences, Faculty of Natural Resources Management and Rural Development, Károly \\ Róbert College, Mátrai str. 36. Gyöngyös, H-3200, Hungarynagypt@ karolyrobert.hu \\ ${ }^{2}$ Institute of Agroinformatics and Rural Development, Faculty of Natural Resources Management and Rural \\ Development, Károly Róbert College, Gyöngyös, Hungary \\ ${ }^{3}$ Institute for Research and Development, Centre of Agricultural and Applied Economic Sciences, University of \\ Debrecen, Debrecen, Hungary \\ ${ }^{4}$ Collage of Kecskemét, Faculty of Horticulture, H-6000 Erdei Ferenc tér 1-3.
}

\begin{abstract}
Summary: Foliar nutrition experiment was made to investigate the effect of algae products on fruit quality of apples (Malus domestica Borkh.).

The study was conducted in 2011 at Siófok in West-Hungary on cv. 'Jonagored' and 'Idared'grafted on M9 rootstock.

In our trial leaf diagnostic and fruit quality measurements were made to study the effectiveness of applied products. Relative leaf chlorophyll content was determined by a portable chlorophyll meter. Fruit weight and shape index were measured. Fruit inner qualifying parameters like titratable acid content and Brix value were also determined.

It can be stated that the used products had traceable effect on investigated fruit parameters. Although, leaf $\mathrm{N}$ content was not effected by treatments significantly, relative leaf chlorophyll content significantly increased by both treatments.

Used products significantly increased the fruit weight and shape index. Applied treatments significantly decreased the $\mathrm{pH}$ of pulp. Treatments increased the acid contents (fumaric, citric, malic) of apples and decreased the amount of monosaccharides. It means that the applied treatments pushed out the ratio of acid/sugar.
\end{abstract}

Key words: Malus domestica Borkh., biostimulators, fruit quality

\section{Introduction}

At present, the growing interest in ecological methods of fruit production, as well as decreasing number of synthetic chemical products allowed for use in the orchards, motivate to search for new biological formulations to replace the chemical agents (Rademacher 2004). Therefore, the role and impact of biostimulators are increasing all over the world. In recent years biostimulators are used frequently not only in crop production but in horticulture as well.

Biostimulators are natural growth regulators or chemicals, most of them contain plant hormones as auxin, gibberellic acid, cytokinins and aminoacids. Some of them contain additive macro and micro nutrients.

Effects of these components increase physiological activities in plants, first of all protein synthesis. Biostimulators help plants surviving stresses. These are used for protect fruit plants from spring frost damage.

According to Basak and Mikos-Bielak (2008) biostimulators cause development of unusually strong flowers on apple trees. Their application result in production of large fruits in the year of application and in the abundant flowering in the following year.
At pear, Btlaszczyk, 2008 pointed out that the biostimulator used had beneficial influence on some internal fruit quality traits, as fruit firmness and titratable acidity, during the storage and maturation.

Seaweed is commonly used as biostimulator due to its beneficial effects.

The application of seaweed extract for different crops was a great importance due to contain high levels of organic matter, micro elements, vitamins and fatty acids and also rich in growth regulators such as auxins, cytokinin and gibberellins (Crouch and Van Staden, 1994).

Seaweed extracts, containing naturally occurring auxins, cytokinins, and gibberellic acids, increase root mass and the root:shoot ratio in several horticultural crops (Featonby Smith and Van Staden, 1983; Finnie and Van Staden, 1985; Nelson and Van Staden, 1984).

Application of seaweed extract increased chlorophyll content (Whapham et al., 1993; Thirumaran et al., 2009). Turan and Köse (2004) observed increases in yield as well as $\mathrm{N}, \mathrm{P}$ and $\mathrm{K}$ with application of seaweed extract on grapevine.

Abdel Mawgoud et al. (2010) cleared that application of seaweed extract at concentrations of 1,2 and $3 \mathrm{~g} / \mathrm{L}$ increased the response of all growth parameters and yield of watermelon. 
Table 1: Nutrient concentrations in NP2

\begin{tabular}{|l|c|c|c|c|c|c|c|c|c|c|c|c|}
\hline & $\mathrm{N}$ & $\mathrm{P} 2 \mathrm{O} 5$ & $\mathrm{~K} 2 \mathrm{O}$ & $\mathrm{MgO}$ & $\mathrm{Fe}$ & $\mathrm{Zn}$ & $\mathrm{Mn}$ & $\mathrm{B}$ & $\mathrm{Cu}$ & $\mathrm{Mo}$ & $\mathrm{Co}$ \\
\hline & \multicolumn{9}{|c|}{ w/w \% } \\
\hline NP2-B & 0.06 & 0.03 & 0.14 & 0.029 & 0.004 & 0.007 & 0.005 & 0.081 & 0.002 & $2 . \mathrm{E}-07$ & $1 . \mathrm{E}-07$ \\
\hline NP2-Ca & 0.13 & 0.03 & 0.14 & 0.029 & 0.004 & 0.007 & 0.005 & 0.005 & 0.002 & $2 . \mathrm{E}-07$ & $1 . \mathrm{E}-07$ \\
\hline NP2-K & 0.2 & 0.03 & 0.61 & 0.029 & 0.004 & 0.007 & 0.005 & 0.005 & 0.002 & $2 . \mathrm{E}-07$ & $1 . \mathrm{E}-07$ \\
\hline NP2-Zn & 0.06 & 0.03 & 0.14 & 0.029 & 0.004 & 0.061 & 0.005 & 0.005 & 0.002 & $2 . \mathrm{E}-07$ & $1 . \mathrm{E}-07$ \\
\hline
\end{tabular}

The beneficial effect of seaweed extract application is as a result of many components that may work synergistically at different concentrations, although the mode of action still remains unknown (Fornes et al., 2002).

The objective of this study was to determine the influence of foliar applications of biostimulator material (Natur Plasma - algae suspension) on chlorophyll and $\mathrm{N}$ content of leaves and fruit parameters like weight, shape index, skin colour, acid and sugar content of apples.

\section{Materials and methods}

The study was conducted in an apple orchard (Malus domestica Borkh.) in 2011 at Siófok in West-Hungary on cv. 'Jonagored' and 'Idared'grafted on M9 rootstock. Trees were planted in the spring of 1999 . Trees spaced $4 \times 1 \mathrm{~m}$, and growing in a calcareous chernozem soil. For the purpose of the experiment, 2 ha areas were randomly selected from the orchard.

For treating, 'Natur Plasma' microbiological products were used, coded as NP1 and NP2.

The composition of NP1 was the following: base material: Chlorella vulgaris algae concentrate in water suspension with $0.3(\mathrm{~m} / \mathrm{m} \%)$ dry matter content at least. The total number of algae was $3 \times 10^{7}(\mathrm{db} / \mathrm{mL})$ at least. The $\mathrm{pH}$ of NP1 was $6.7 \pm 0.5$.

The composition of NP2 was: NP1 base solution with additional macro and micronutrient contents (Table 1.)

The applied foliar applications are presented in Table 2.

The treatments were made before blooming time and then every 2-3 week till the harvest time (Table 2.) The control treatment was the basic treatment without products of Natur Agro Hungária Ltd.

In our trial leaf diagnostic and fruit quality measurements were made to study the effectiveness of applied products.

Table 2: Treatments of the experiment

\begin{tabular}{|c|c|c|c|}
\hline Time of & \multicolumn{2}{|c|}{ Treatment } & Dose \\
\hline 11. IV.2011. & NP1 & NP2-B & \multirow{7}{*}{$\begin{array}{c}\text { 10L /1000L } \\
\text { water/ha }\end{array}$} \\
\hline 30. IV. 2011. & NP1 & NP2-B & \\
\hline 23. V. 2011. & NP1 & NP2-Ca & \\
\hline 10. VI. 2011. & NP1 & NP2-Ca & \\
\hline 27. VI. 2011. & NP1 & NP2-Ca & \\
\hline 18. VII. 2011. & NP1 & NP2-Ca & \\
\hline 1. VIII. 2011. & NP1 & NP2-B/K & \\
\hline
\end{tabular}

As the chlorophyll content of leaves is linked to nitrogen content and chlorophyll measurement may provide information on the plant physiological state hence, to photosynthesis in our investigation relative leaf chlorophyll content was determined by a portable chlorophyll meter (SPAD 502+, Minolta, Japan) and leaf $\mathrm{N}$ by Kjeldahl method.

For measuring leaf $\mathrm{N}$ and chlorophyll content healthy, fully developed leaves were collected from the mid-third portion of current season extension shoots. Leaf samples were collected 100 days after full bloom, from uniform trees. The mean of five readings from the chlorophyll meter was obtained for each leaf (10 developed leaves). For leaf $\mathrm{N}$ measuring dried, homogenized samples were used.

Fruit inner qualifying parameters like titrable acid content and Brix value were also determined. Titrable acid content was measured by potentiometric titration according to Hungarian standard (MSZ EN 12147:1998). Brix values were measured by hand refractometer (ATAGO PAL series).

Data of leaf and fruit analysis were subjected to analysis of variance (ANOVA) and means were separated by Duncan's significant difference test at $\mathrm{P}<0.05$.

\section{Results and discussion}

\section{Results of field observations}

Visual field survey was held to estimate the growing experiences in the vegetation period, directly before the harvest (22. September 2011).

Our observations were the following:

1. Spraying of used products was made separately. Spraying problems (precipitation, phase separation, inhomogenity) were not observed during the spraying. Corrosion or clogging in the sprinkler head was not observed.

2. Leaf burning symptoms were not observed after foliar application.

3. Adsorption of the products was excellent on the leaf surface.

4. Absorption of the products was satisfactory.

5. The leaf colour was greener, healthier and brighter at treated trees compared to the control leaves of trees.

6. Skin colour of treated apples was more intensive and completed than control apples (Photos 1-6). 


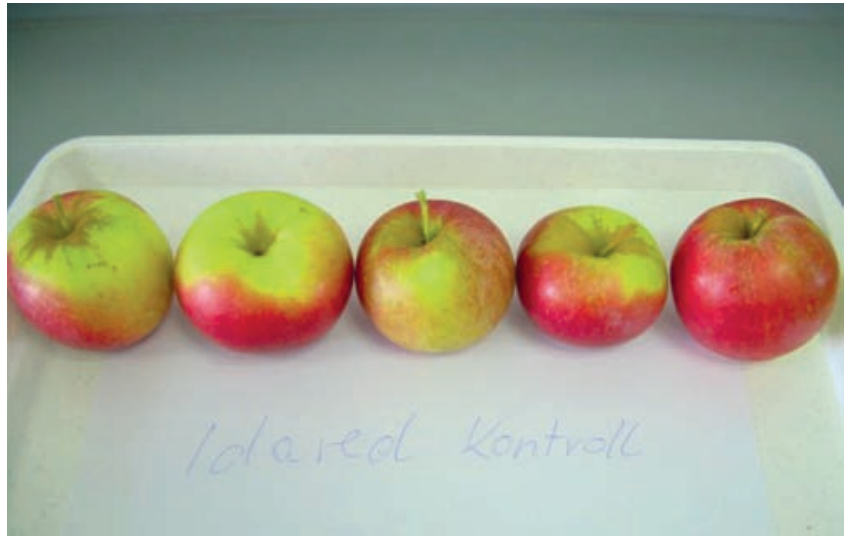

Photo 1. 'Idared' control

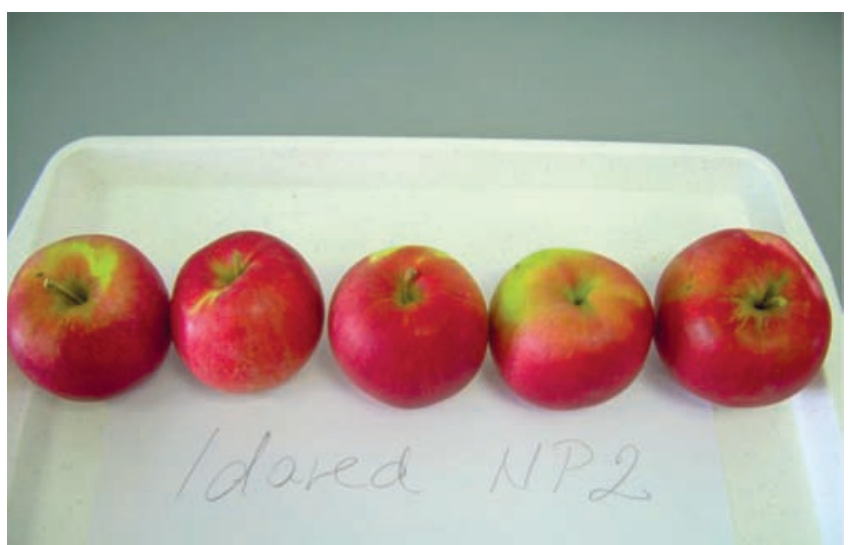

Photo 3. 'Idared' treatment NP2

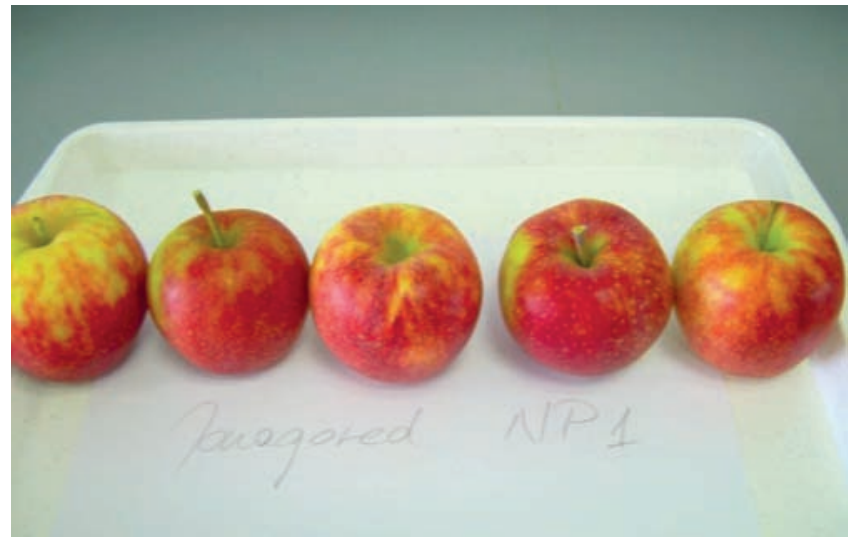

Photo 5. 'Jonagored' treatment NP1

\section{Results of leaf analysis}

Results of leaf $\mathrm{N}$ and chlorophyll measurements were presented in Table 3.

From the results it was evident that the value of SPAD was depended on variety. Moreover, applied treatments also had significant effect on SPAD values. Both treatments increased the relative chlorophyll content of leaves. This result is correlation with field observations. Obtained result may be explained by the positive effect of "Chlorella vulgaris' algae suspension on chlorophyll developing, by improving working of cloroplastis.

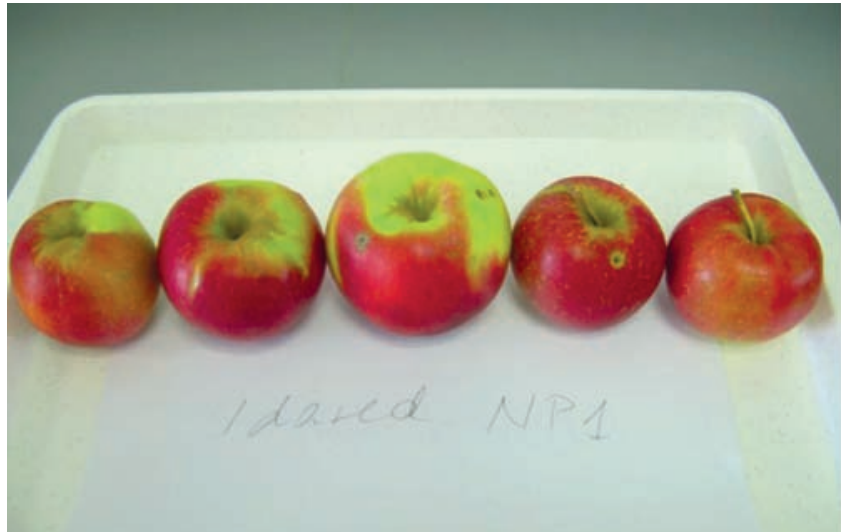

Photo 2. 'Idared' treatment NP1

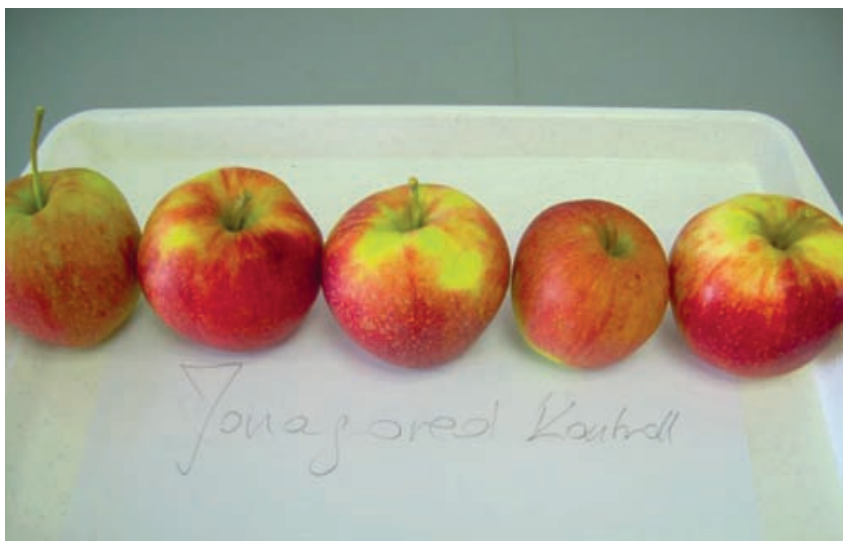

Photo 4. 'Jonagored' control

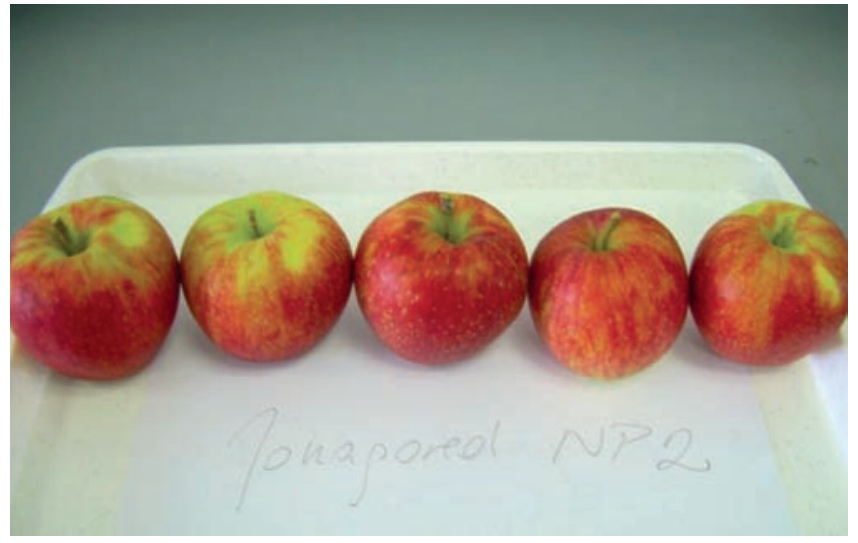

Photo 6. 'Jonagored' treatment NP2

Table 3. Effect of treatments on leaf relative chlorophyll contents

\begin{tabular}{|l|c|c|}
\hline \multicolumn{1}{|c|}{ Variety / Treatments } & N\% & $\begin{array}{c}\text { Relative chlorophyll } \\
\text { content (SPAD) }\end{array}$ \\
\hline Idared / Control & $2,14 \mathrm{a}$ & $55,2 \mathrm{a}$ \\
\hline Idared / NP1 & $2,27 \mathrm{a}$ & $59,8 \mathrm{~b}$ \\
\hline Idared / NP2 & $2,25 \mathrm{a}$ & $62,2 \mathrm{~b}$ \\
\hline Jonagored / Control & $2,11 \mathrm{a}$ & $51,5 \mathrm{a}$ \\
\hline Jonagored / NP1 & $2,14 \mathrm{a}$ & $53,4 \mathrm{~b}$ \\
\hline Jonagored / NP2 & $2,15 \mathrm{a}$ & $53,9 \mathrm{~b}$ \\
\hline
\end{tabular}

In each column, means followed by the same letter are not significantly different $(\mathrm{P}<0.05)$. 
It seems that applied products help photosynthetic process and improves plant metabolism. Although, leaf $\mathrm{N}$ content was not effected by treatments significantly it can be state that applied products increased leaf $\mathrm{N}$ content at both varieties. Our finding confirm previous research using SPAD to estimate $\mathrm{N}$ availability in apple (Neilsen et al., 1995) showed a significant relationship between $\mathrm{N}$ rate and SPAD measurements for four varieties of apple.

\section{Results of fruit analysis}

Results of fruit analysis are presented in Table 4.

It can be state that both used products significantly increased the fruit weight. The fruit weight development was varied by variety and treatment. The degree of increment varied between $3.8-5.4 \%$ at 'Idared' and $10.8-18.3 \%$ at 'Jonagored'. It seems that the products improved the cell division and nutrients incorporation.

Our results pointed out that the shape index of apples was increased by both treatments. This finding is correlated with the weight-development of apples.

Applied treatments significantly decreased the $\mathrm{pH}$ of pulp except of NP2 treatment at 'Idared'. According to this, the titrable acid content of apples was increased by the treatments except of NP2 treatment at 'Idared'.

Table 4. Results of fruit analysis

\begin{tabular}{|l|c|c|c|c|c|c|}
\hline & Weight $(\mathrm{g})^{*}$ & $\begin{array}{c}\text { Weight- } \\
\text { development } \\
(\%)^{* *}\end{array}$ & $\begin{array}{c}\mathrm{Si}^{* * *} \\
(\mathrm{~mm} / \mathrm{mm})\end{array}$ & $\mathrm{pH}$ & $\begin{array}{c}\text { Titrable acid } \\
\text { content }(\%)\end{array}$ & Brix $^{\circ}$ \\
\hline Idared Control & $179.78 \mathrm{a}$ & - & $55.0 / 60.5$ & $3.35 \mathrm{~b}$ & $0.58 \mathrm{a}$ & $14.2 \mathrm{~b}$ \\
\hline Idared NP1 & $186.72 \mathrm{~b}$ & 3.8 & $50.5 / 67$ & $3.00 \mathrm{a}$ & $0.70 \mathrm{~b}$ & $14.3 \mathrm{~b}$ \\
\hline Idared NP2 & $189.55 \mathrm{~b}$ & 5.4 & $57.8 / 66.5$ & $3.34 \mathrm{~b}$ & $0.49 \mathrm{a}$ & $13.4 \mathrm{a}$ \\
\hline Jonagored Control & $194.26 \mathrm{a}$ & - & $60.2 / 66.3$ & $3.70 \mathrm{~b}$ & $0.41 \mathrm{a}$ & $15.5 \mathrm{~b}$ \\
\hline Jonagored NP1 & $215.20 \mathrm{~b}$ & 10.8 & $64.4 / 71.7$ & $3.28 \mathrm{a}$ & $0.49 \mathrm{~b}$ & $14.3 \mathrm{a}$ \\
\hline Jonagored NP2 & $229.90 \mathrm{~b}$ & 18.3 & $64.8 / 71.8$ & $3.25 \mathrm{a}$ & $0.48 \mathrm{~b}$ & $14.5 \mathrm{a}$ \\
\hline
\end{tabular}

In each column, means followed by the same letter are not significantly different $(\mathrm{P}<0.05)$.

*weight is presented as mean weight of ten fruits

**weight development is expressed as increment \% compared to control

$* * *$ shape index is expressed as the ratio of height/width

Soluble solid content of apples was decreased by treatments, except except of NP1 treatment at 'Idared'. Summarized our results it can be stated that the used products had traceable effect on investigated fruit parameters. Treatments increased the acid contents (fumaric, citric, malic) of apples and decreased the amount of monosaccharides. It means that the applied treatments pushed out the ratio of acid/sugar.

\section{Acknowledgements}

We want to thank NFÜ TECH_08-A4/2-2008-0138 and TECH_08-A3/2-2008-0373 projects for financial assistance. Special thanks to Natur Agro Hungária Ltd. to products.

\section{References}

Abdel-Mawgoud, A. M. R., A. S. Tantawy, Magda M . Hafez and Hoda A. M. Habib 2010. Seaweed extract improves growth, yield and quality of different watermelon hybrids. Research Journal of Agriculture and Biological Sciences, 6 (2): 161-186.

Basak, A., Mikos-Bielak, M. 2008. The use of some biostimulators on apple and pear trees. [In: Z.T. Dabrowski (ed.): Biostimulators in modern fruit agriculture] p. 7-17.

Błlaszczyk, J. 2008. Quality of 'Conference` pears as affected by goëmar bm 86 and fruton. [In: Biostimulators in modern agriculture: Fruit crops. (Ed.:Z.T. Dabrowski)] p. 18-24.

Carter, G. A. 1994. Ratios of leaf reflectances in narrow wavebands as indicators of plant stress. International Journal of Remote Sensing, 15 (3): 697-703.

Crouch, I.J., Van Staden, J. 1994. Commercial seaweed products as Biostimulants in horticulture. Journal of Home and Consumer Horticulture, (1): 19-76.

Evans, J. R. 1989. Photosynthesis and nitrogen relationships in leaves of C3 plants. Oecologia, 78: 9-19.

Finnie, J.F, and J. Van Staden. 1985. Effect of seaweed concentrate and applied hormones on in vivo cultured tomato roots. J. Plant Physiol., 120: 215-222.

Featonby. S. , B. C. and J. Van Staden, 1983. The effect of sea weed concentrate on the growth of tomato plants in nematode infested soil. Scientia Horticulturae, 20 (2): 137-146.

Fornes, F., Sánchez-Perales, M., Guadiola, J.L. 2002. Effect of a seaweed extract on the productivity of 'de Nules' Clementine mandarin and navelina orange. Botanica Marina, 45: 486-489.

Lichtenthaler, H. K. 1998. The stress concept in plants: An introduction. Annals of the New York Academy of Science, 851: 187-198.

MSZ EN 12147: 1998. Gyümölcs- és zöldséglevek. Titrálható savasság meghatározása. Magyar Szabványügyi Testület. (Hungarian)

Nelson, W.R. and J. Van Staden. 1984. The effect of seaweed concentrate on growth of nutrient-stressed greenhouse cucumbers. Hort. Science, 19: 81-82.

Neilsen, D., Hogue, E.J., Neilsen, G.H., Parchomchuk, P., 1995. Using SPAD-502 values to assess the nitrogen status of apple trees. Hortscience, 30 (3): 508-512.

Rademacher, W. 2004. Recent situation and trends in global plant bioregulator utilization. Regulation of Plant Growth and Development, 39 (1): 142-151.

Thirumaran, G., M. Arumugam, R. Arumugam and P. Anantharaman 2009. Effect of sea weed liquid fertilizer on growth and pigment concentration of Cyamopsis tetrogonolaba $\mathrm{L}$ Taub. Am-Euras. J. Agron., 2 (2): 50-56.

Turan, K. and Kose, M. 2004. Seaweed extract improve copper uptake of Grapevine (Vitis vinifera ) Act Agric Scand, B, Soil Plant Sci., (54): 213-220.

Whapham, C. A, Blunden, G, Jenkins, T and Wankins, S. D, 1993. Significance of betaines in the increased chlorophyll content of plants treated with seaweed extract Appl Phycology, 5: 231-234.

Yoder, B. J., \& Pettigrew-Crosby, R. E. 1995. Predicting nitrogen and chlorophyll content and concentrations from reflectance spectra (400-2500 nm) at leaf and canopy scales. Remote Sensing of Environment, 53 (3): 199-211 